\title{
Investigating the Effect of Blending MOOCs with Flipped Classroom on Engagement in Learning and Course Grades. Toward a Flipped Learning Approach to MOOCs
}

\author{
Nahed F. Abdel-Maksoud ${ }^{1}$ \\ ${ }^{1}$ Damietta University, Egypt \\ Correspondence: Nahed Fahmy Abdel-Maksoud, Damietta University, Egypt.
}

Received: May 12, 2019; Accepted: May 26, 2019; Published: June 24, 2019

\begin{abstract}
Though MOOCs are usually used as stand-alone online courses, more and more instructors are using them to complement their traditional lectures, others are using them to flip their classrooms. This study investigates the impact of MOOCs-based flipped classroom on engagement in learning and course grades. This quasi-experimental study employed post-test only control group design. Participants of the study consisted of 155 pre-service teachers studying the undergraduate "EFL Teaching Methodology course at one of the universities in Egypt in the year 2018-2019. Participants were randomly assigned to either an experimental (flipped classroom) $(N=78)$ or a control group (traditional) $(N=77)$. Both groups were taught by the same instructor, the control group was taught in the traditional method, while the experimental group were required to enroll in two English Language Teaching MOOCs, assigned by the course instructor, and complete specific parts of each course, students had to watch videos, read articles, complete quizzes, and come to class prepared to discuss what they have read and watched, and complete in-class activities. Ten weeks later, the instrument of the study, Engagement Scale, was administered to both groups to assess their engagement in learning. Course grades were obtained from the instructor. Results showed that there were statistically significant differences in both engagement and course grades in favor of the experimental group (flipped classroom group). Using MOOCs to flip traditional courses is found to improve students' engagement and learning, this is because students were able to use limited class time to engage in higherlevel interactive learning activities. There is no fear that technology or video lectures will replace faculty, rather it can make their teaching more effective. Integrating MOOCs and flipped classroom can harness technology to radically redesign teaching and learning experiences.
\end{abstract}

Keywords: Massive Open Online Courses (MOOCs), Flipped Classroom, Engagement in Learning, Course Grades, EFL Teaching, Pre-service Teachers

\section{Introduction}

Over the last decades web technologies have drastically changed the way people live, work, communicate, and learn (Fondo \& Konstantinidis, 2018). Besides, rapid changes in knowledge created a massive need for learning and training. Massive Open Online Courses MOOCs emerged. The MOOCs described as an "evolution", "tsunami", "revolution in education", the future of education mark the biggest change in the way people learn and teach. Though MOOCs are usually used as stand-alone online courses, MOOCs also could be used to support traditional classroom settings. More and more instructors are using MOOCs to complement their traditional lectures. Others are using MOOCs to flip their classrooms. Instructors can use the content for a MOOC in a "flipped" course in which students have to watch videos, and answer automated quizzes in their own time and then come to class ready to interact one on one with an instructor, and work on advanced problems. This study is trying to integrate the content of two MOOCs in a flipped undergraduate classroom setting, and report its impact on engagement and course grades.

\section{Significance of the Study}

To ensure maximum benefit of MOOCs, there is a need to evaluate their potentials for integration into traditional higher education systems. Teachers do not need to create tutorials and presentations that students watch outside classrooms, there are hundreds of MOOCs for every topic to choose from. A flipped learning approach to MOOCs can help instructors benefit from the high quality learning materials provided by the MOOCs, and at the same time help students engage in learning, and stay on track, which will ensure increased persistence and learning outcomes. 
Flipped classroom is an innovative instructional model, and it can become more effective if MOOCs are blended into it. There is limited evidence that Flipped classroom approach has on learning outcomes (O'Flaherty \& Phillips, 2015). Studies focusing on students' perceptions on flipped classroom were mostly positive, but there are very few studies that found flipped learning approach more effective than traditional teaching methods (Molnar, 2017).This study will put this approach to test in real world.

\section{Contribution}

This study can add further weight to an emerging consensus that MOOCs can be integrated with traditional courses to attain reduced teaching time without compromising student outcomes.

\section{Problem}

Despite the growth in MOOCs, there are some issues surrounding their successful implementation; one such issue is the high dropout rate (Alraimi, Zo, \& Ciganek, 2015; Hew \& Cheung 2014). Although the enrollment rates in MOOCs are very high, the majority of MOOC learners do not successfully complete MOOCs. Completion rates are typically very low, 3\%-6\% (Breslow, Pritchard, DeBoer, Stump, Ho \& Seaton, 2013; Jordan, 2014). For instance, the Massachusetts Institute of Technology (MIT) provided its first MOOC in 2012 and 155,000 of in it; students enrolled however, the dropout rate was more than 95\% (Uvalic-Trumbic \& Daniel, 2013). Considering that developing and operating MOOCs requires much more monetary investment compared than traditional courses do (Hollands \& Tirthali, 2014), such low learning persistence statistics are considered obstacles that weaken MOOCs' sustainability and effectiveness. Furthermore, the low participation creates concerns, because effective learning occurs when learners take an active, leading role in the learning process rather than just receiving information from instructors (Johnson-Farmer \& Frenn, 2009; Kember, 2009). A major defect of MOOCs is that students do not engage actively in online discussion forums provided by the MOOCs (Bruff et al., 2013; Caulfield, Collier \& Halawa, 2013); rather they prefer to interact face-to-face in the classroom.

To address these problems, many educators experimented with the idea of integrating MOOCs into their classes. Research studies yielded unequivocal findings. Some studies report that MOOCs enrich traditional face to face learning environments, and there are many examples of MOOCs being blended into on-campus courses (e.g. Bruff, Fisher, McEwen \& Smith, 2013; Jaffer, Govender, and Brown, 2017; Yousef, Chatti, Schroeder \& Wosnitza, 2015). Other studies reported that the impact of incorporating MOOCs in traditional classroom settings was almost equal or slightly better than face-to-face teaching environments (Bruff et al., 2013; Caulfield et al., 2013; Griffiths, Chingos, Mulhern \& Spies 2014; Holotescu, Grosseck, Cretu \& Naaji, 2014), On the other hand, the studies done by Firmin, Schiorring, Whitmer, Willett, Collins, \& Sujitparapitaya (2014), and Griffiths et al. (2014) reported poor student outcomes. These contradictory results necessitate further investigation of the impact of integrating MOOCs into traditional higher education courses.

The current study investigates the impact of integrating MOOCs into traditional courses through a flipped learning approach. Studies related to flipped classroom approach focused mostly on students' perceptions, which were generally positive, but very few studies found that the flipped learning approach is more effective than conventional teaching methods. (Molnar, 2017; O'Flaherty \& Phillips, 2015). While some studies referred to a modest improvement of academic performance or improved student satisfaction, there is currently limited evidence that flipped classroom can affect learning outcomes, especially in higher education. Therefore, further research is required in that area (Molnar, 2017).

\section{Research Questions}

RQ1: Is there a statistically significant difference in engagement in learning between the experimental group (flipped classroom), and control group (traditional classroom)?

RQ2: Is there a statistically significant difference in course grades between the experimental group (flipped classroom), and control group (traditional classroom)?

\section{Related Literature}

\subsection{MOOCS}

\subsubsection{What are MOOCs?}

MOOCs are high quality open access courses that operate on a vast scale, that are available to anyone and anytime, online, and for free. MOOCs opened doors to people around the world to take great online courses from prestigious universities for free. MOOCs are characterized by having a syllabus that has specific objectives and outcomes, a calendar, educational materials, mainly videos, some activities, some quizzes and exams, and a discussion forum. McAuley, Stewart, Siemens \& Cormier (2010) define a MOOC as an online course with the option of free and 
open registration, a publicly-shared curriculum, and open-ended outcomes. MOOCs integrate social networking, accessible online resources, and are facilitated by leading practitioners in the field of study. Most significantly, MOOCs build on the engagement of learners who self-organize their participation according to learning goals, prior knowledge and skills, and common interests. Building upon McAuley et al. (2010) definition of MOOC, here are a number of features that are typically required for a course to be considered a MOOC:

- Massive: It should allow access to a very large number of students, and therefore, should be designed to accommodate for numbers of students, up to 100,000 students, without major operation problems.

- Online: The course does not require classroom attendance; it is remotely accessed via the internet, which means that anyone from anywhere in the world with an internet connection can enroll in such courses.

- Open: It should be open, which means that it can be accessed by anyone, and should not require some prerequisites, besides, the access to educational resources is free.

- Course: It should have same components as any course, objectives, activities, a beginning and an end, some quizzes and exams, and some kind of interaction between students and teachers.

\subsubsection{Types of MOOCs}

There are two types of MOOCs proposed by Siemens (2013), First: cMOOCs or, Connectivist which put emphasis on connected and collaborative learning. These MOOCs are linked to a view of learning promoted by Siemens and Downes called Connectivism, a combination of network learning and the pedagogy of participation, ccording to which knowledge is a social construct and is distributed over networks of connections through participants' engagement, self-direction, creativity, collaboration and social networking.Second: $x M O O C s$, which are considered as an extension of the traditional on-line courses; they are based on the model of knowledge transfer to the learners, with a focus on of learning content, and emphasizing individual learning rather than learning within groups of peers. This type of MOOCs, xMOOCs, were developed and offered by traditional universities (Stanford (Coursera), MIT/ Harvard (edX), Udacity, etc.) (Fidalgo-Blanco, Sein-Echaluce \& García-Peñalvo, 2016; Ng \& Widom, 2014; Siemens, 2012).

\subsubsection{Background of MOOCs}

According to Crosslin, Dellinger, Joksimović, \& Kovanović, (2018), MOOCs can be seen as the natural evolution of Open CourseWare, initially created by Massachusetts Institute of Technology in 2001. Therefore, no wonder that MIT also leads the development of MOOCs, first with MITx (Massachusetts Institute of Technology, 2011), and then with edX (Massachusetts Institute of Technology, 2013).

The first MOOC course, Connectivism and Connective Knowledge (CCK08), designed by George Siemens and Stephen Downes at the University of Manitoba (Canada), was offered in 2008, and was initially designed as an open online course (Kovanović, Joksimović, Gašević, Siemens \& Hatala, 2015). In this course, 24 fee-paying oncampus students and approximately 2,200 students from the general public were enrolled, which was then considered a massive number (Mackness, Mak \& Williams, 2010). This initial surprising numbers led Dave Cormier, from the University of Prince Edward Island (Canada), to coin the term "massive open online course" (Dabbagh, Benson, Denham, Joseph, Al-Freih, Zgheib, \& Guo, 2016). Siemens and Downes had designed the course to be an experiment in a new learning theory that they had recently begun working out, called connectivism (Kovanović et al., 2015).

Though this course did not have the same success as current MOOCs, but it paved the way for the current

MOOCs. The first MOOC that had an amazing success was: "Introduction to Artificial Intelligence" organized in 2011, by Sebastian Thrun, a professor at Stanford University, and Peter Norvig, Google's research director. About 160,000 people from all over the world enrolled in this course. The next MOOC that was very successful was: "Circuits \& Electronics" offered in 2012, by the Massachusetts Institute of Technology (MIT). In this course, more than 120,000 people signed up, and this trend continues in the following MOOCs.

In their 2018 vision report, MOOCWATCH reported that MOOCs crossed 100 Million learners in 2018, to reach a total of 101 million. The Top five MOOC providers by registered users were: Coursera: 37 million, edX: 18 million, XuetangX: 14 million, Udacity: 10 million, and FutureLearn: 8.7 million (Shah, 2018).

\subsubsection{Criticism of MOOCs}

Despite the fact that MOOCs have gained much momentum in recent years, there are still many problems associated with them which need to be resolved. Pedagogically, xMOOCs have been criticised for employing a knowledge transmission model; they are considered to be technology-enriched traditional teacher-centred instruction. In other words, they do not provide a social learning experience. By contrast, cMOOCs provide good 
opportunities for non-traditional forms of teaching approaches and learner-centred pedagogy where students learn from one another (Armellini \& Padilla Rodriguez, 2016). However, MOOCs in general tend to have a low completion rate due to high dropout rate, which can reach 90\% or more (Clow, 2013; Lewin, 2013; Watson, Watson, Yu, Alamri, \& Mueller, 2017; Freitas, Morgan, \& Gibson, 2015; Onah, Sinclair, Boyatt, \& Foss, 2014). While millions of people enroll in MOOCs, the dropout rate of most courses can reach $90 \%$ (Jordan, 2014; Hew $\&$ Cheung, 2014). Factors leading to this very high dropout rate were found to be course structure and content, workload and duration, type of assessments and feedback, and type of interaction with students and instructors, etc. (Adamopoulos, 2013).

Traditional face-to-face education provides benefits that cannot be easily replicated in online education. For example, in teachers traditional education can observe the progress of students and can help them to resolve problems when necessary. Besides, the personal interaction is completely missed out in MOOCs (Luján-Mora \& Saquete, 2013). In sum, MOOCs have raised awareness about the potential of online technology and sparked technological and pedagogical innovation that helped expand higher education opportunities to more people, at home and abroad (Sandeen, 2013). But if they are to be successfully implemented as stand-alone courses, or integrated into the current traditional courses, more and more research is needed.

\subsection{Flipped Classroom}

\subsubsection{What's Flipped Classroom?}

The advancement in technological tools such as interactive videos, interactive in-class activities, and video conference systems paves the way for the widespread use of flipped classrooms (Johnston, 2017). It is believed that flipped learning is the best model for using technology in education (Hamdan, McKnight, McKnight, \& Arfstrom, 2013). The history of flipped classroom began in 1993 when Alison King published "From Sage on the Stage to Guide on the Side" In the article; King focuses on the importance of the use of class time for the construction of meaning rather than information transmission. While not directly illustrating the concept of "flipping" a classroom, King's work is often cited as an impetus for an inversion to allow for the educational space for active learning. The concept of flipped classroom got a big boost when it was embraced by Salman Khan who proposed it as a suitable strategy to make effective use of video lectures in his Khan Academy Library. Perhaps the most recognizable contributor to the flipped classroom is Salman Khan (Thompson, 2011). In 2004, Khan began recording videos at the request of a younger cousin he was tutoring because she felt that recorded lessons would let her skip segments she had mastered and replay parts that were troubling her. Salman Khan founded Khan Academy based on this model. For some, Khan Academy has become synonymous with the flipped classroom; however, these videos are only one form of the flipped classroom strategy.

Flipped classroom is an instructional strategy which consists of two main components: the use of technologies such as video lectures often outside classroom and the taking part in interactive meaningful learning tasks inside classroom. Moreover, flipped classroom reverses the typical order in which students learn, listen to lectures at class, and then work on homework elsewhere. In this new method students watch lectures on videos at home, and then come to class for discussion and interaction with teacher and other students. Studies show that videos are often used as a means of teaching outside the classroom, while interactive tasks in which the students are actively participating are used as in-class activities (Basal, 2015; Graziano, 2017; Hsu, 2017; Roehling, Root Luna, Richie, \& Shaughnessy, 2017; Song \& Kapur, 2017; Zengin, 2017).

In the classroom students are expected to interact with the instructor and their peers, apply and practice the knowledge, and higher order thinking skills, therefore, it is imperative that instructors apply active learning strategies to enable learners to manage their learning process (Wiginton, 2013). A flipped classroom combines constructivist and behaviorist principles. Behavioral learning theory is based on traditional classroom instruction, while constructivism highlights individual's personal experience on constructing and understanding knowledge (Hawks, 2014). The flipped classroom model "provides students with more control over their learning", and "gives students a greater sense of their own responsibility for their learning" (Baker, 2000, 11). Surveys show that over two-thirds of students prefer a properly conducted flipped class over conventionally taught classes (Franzon, 2013).

\subsubsection{Flipped Classroom and Engagement in Learning}

Flipped classroom is an innovative pedagogical approach that enhances students' engagement (Tucker, 2012), which has always been a challenge for instructors. Flipped classrooms transform the roles of teachers and students, and compel the teachers to come up with new plans (Jinlei, Ying \& Baohui, 2012). As flipped classroom revolutionized the way students receive information from educators as it paved the way for more student engagement in the learning process. More engagement in flipped classroom is enabled as the students use their classroom hours to deepen their understanding of the subject (Klem \& Connell, 2004) and apply the knowledge 
obtained prior to the class time. In a flipped classroom, as the teachers walk around interacting with students (Stone, 2012) students feel more engaged and attached to lessons taught. Overall, research studies found that student engagement in learning increased with the flipped classroom (Baker, 2000; Bergmann \& Sams, 2012; Brown, 2012; Hamdan et al., 2013

\subsection{Engagement in Learning}

Engagement is a complex construct and there is no agreement on its meaning till now. Newmann, Wehlage, and Lamborn (1992) define it as the psychological inversion in which the student invests energy and effort to understand something. York, Gibson, and Rankin (2015) indicate that engagement is a term generally used to refer to the student's psychological investment, his or her willingness to invest time in educational behaviors, or to a general reference of student involvement in educational activities.

Engagement in learning is usually seen as how involved students are in the material they study and in the learning process itself. Engagement is defined as "the behavioral intensity and emotional quality of a person's active involvement during a task" (Reeve, Jang, Carrell, Jeon, \& Barch, 2004, 147). Engagement in traditional classroom settings are usually associated with improved course satisfaction, improved motivation, more participation in academic activities, and more success levels success levels (de Barba, Kennedy \& Ainley 2016; Valdivia, RamírezMontoya, \& Valenzuela, 2018).

According to Abdel-Maksoud (2007) students' engagement in learning is significantly related to students' satisfaction, and students' grades, which suggests that students who perceived themselves to be engaged and actively involved in learning were more satisfied with the course than the others. Besides, students who were more engaged in learning achieved better and got higher grades than the others. Engagement in learning is also closely related to motivation. A student is motivated when they express interest in a school task, feel excited about it, or think that it is important and worthwhile. Motivation research has shown that these feelings and beliefs about interest and value lead to more student engagement and learning (Pintrich \& Schunk, 1996).

Student engagement has been defined as involving students in meaningful academic activities (Delialioglu, 2012). Research has shown that engaged students are good leraners (Jang, 2008; Troisi, 2014). One of the challenges teachers face in higher education is that of engaging their students. The teacher's role is to help students engage and interact with learning material so that they can construct their own knowledge (Lumpkin, Achen, \& Dodd, 2015). High levels of student engagement were found to be positively correlated with learning outcomes, and students' perception of their learning experience (Webber, Krylow, \& Zhang, 2013; Delialioglu, 2012; Schlenker, Schlenker \& Schlenker 2013; Troisi, 2014). Interactions with teachers, and other students were found to play an important role in student engagement (Lumpkin et al., 2015). Schlenker et al. (2013) found that setting clear goals, encouraging students to believe in themselves, along with stressing the importance of personal obligation contributed to predicting academic engagement.

Bryson and Hand (2007) proposed that enjoyment, enthusiasm, learning for pleasure of learning itself, and learning more than required about a subject were described as elements of student engagement. Studies have shown that students will tend to invest more effort, and achieve more when a lesson is perceived to have personal importance to them (Miller \& Brickman, 2004; Shell \& Husman, 2001). Zeeman and Lotriet (2013) stress the importance of allowing students to take part in making decisions in order for them to become invested in the learning experience. According to Doyle (2008) creating learner-centered environments can sustain, and enhance student engagement. In learner-centered environments, students remain active in their learning experience, and are responsible for their own learning.

Student engagement is challenging to define as it is a complex construct influenced by multiple factors. According to Fredricks, Blumenfeld \& Paris (2004), engagement is characterized by three dimensions: behavioral (e.g., compliance with attendance and involvement), cognitive (e.g., investment in one's activities and appreciation of challenges), and emotional (e.g., positive affective reactions, including enjoyment and sense of belonging) (Pilotti et al., 2017). The current study adapted engagement framework done by Fredricks et al. (2004), in which engagement is divided into emotional, cognitive and behavioral components. In online self-paced settings, behavioral engagement articulated by Fredricks, Filsecker \& Lawson (2016) can be measured in terms of time-ontask, student persistence in doing the allocated work and the level of effort the student invested toward the completion of the task. In traditional classroom settings, simple behavioral engagement may not be enough in many cases. It may be that students are behaviorally engaged but not cognitively engaged. Simple attention may not be enough for learning. Students should be cognitively engaged, they should think deeply, critically and creatively about the material to be learned. Teachers also want students to be emotionally engaged in the content or tasks to be learned. This means that students should show interest in the content or the materials they learn. 
They should also believe that the content is of value to them; important and worthwhile. Besides, students also should have positive emotions during learning, and should not develop negative emotions such as anxiety (Linnenbrink\& Pintrich, 2003).

This study dealt only with the self-reported perceptions on two facets; cognitive and emotional engagement, that's because it is believed that if students are cognitively and motivationally engaged, they are likely to be behaviorally engaged. However, there may be times when students are behaviorally engaged but not cognitively engaged, as when they would think about something else besides the lesson even though their eyes are on the teacher. This is why it is important for teachers to not rely solely on behavioral indicators of engagement (Linnenbrink \& Pintrich, 2003).

\section{Method}

\subsection{Participants of the Study}

Participants of the study consisted of 155 pre-service teachers studying in the English Language department in the College of Education at one of the universities in Egypt, who were taking the undergraduate "EFL Teaching Methodology" course in the year 2018-2019.Students were then randomly assigned to either the experimental or the control group. Both groups were taught by the same instructor, the control group was taught in the traditional method, while the experimental group were required to enroll in two English Language Teaching MOOCs, assigned by the course instructor, and complete specific parts of each course, that were seen to be suitable for the course objectives, students had to watch videos, read articles, complete quizzes, and come to class prepared to discuss what they have read and watched, and complete in-class activities. Figure 1 and 2 illustrate two of the videos students had to watch before they come to class.

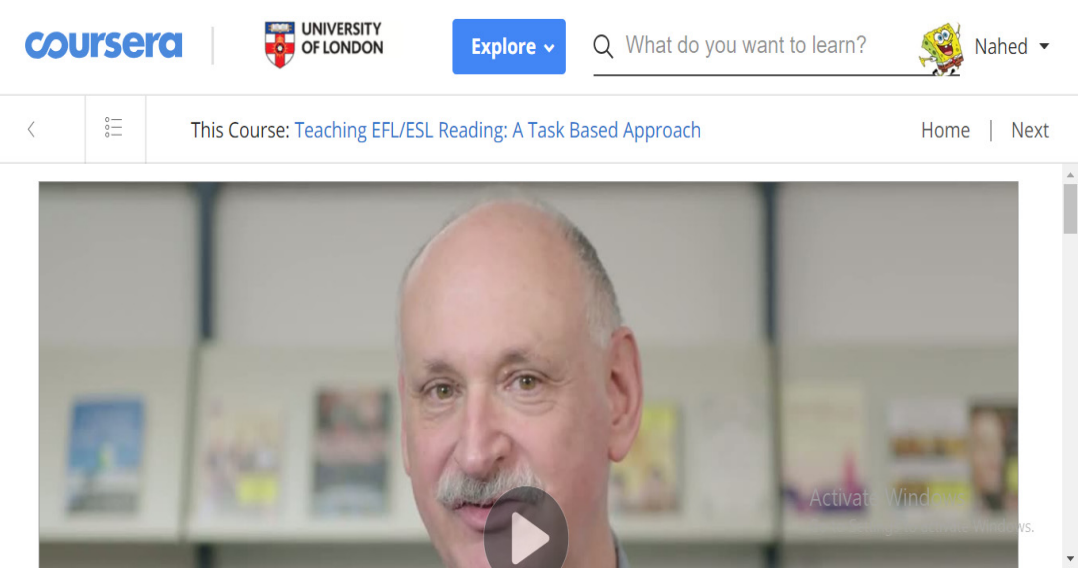

Figure 1. Screenshot of a video From “Teaching ESL/EFL Reading?” by Coursera, 2019

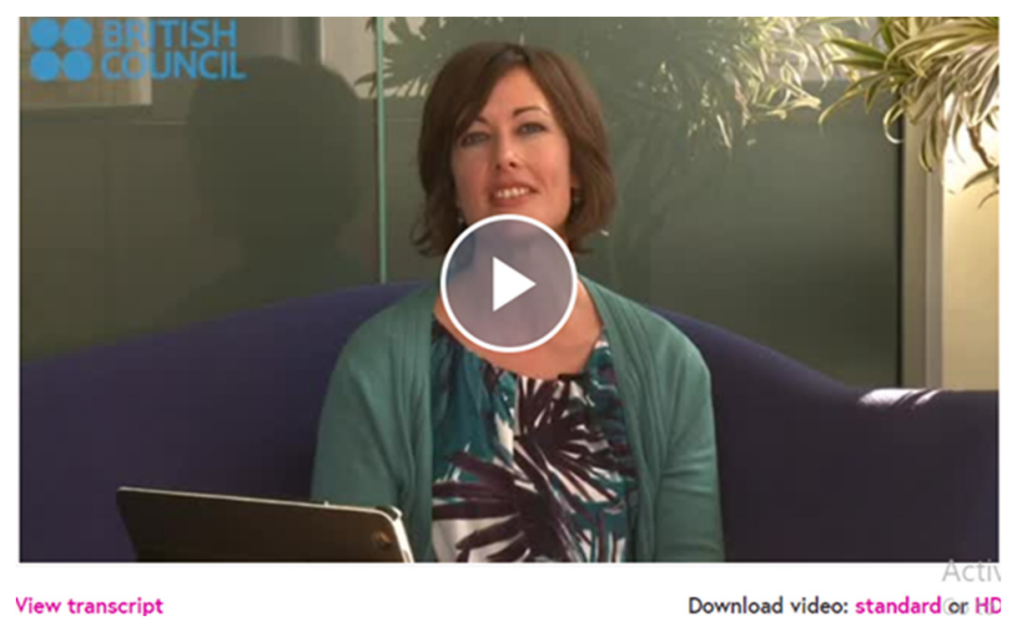

Figure 2. Screenshot of a video From Teaching English: How to Plan a Great Lesson", by FutureLearn 


\subsection{Materials}

The two selected MOOCs were: Coursera "Teaching ESL/EFL Reading: A task-based approach", offered by the University of London \&UCL Institute of Education, and "Teaching English: How to Plan a Great Lesson", offered by the British Council over FutureLearn. For about ten weeks, the flipped classroom FC model was applied with the experimental group, and class time was redesigned to concentrate on discussions, individual presentations and group projects.

In class activities for the experimental group included short quizzes, individual 25-minute presentation on one of the course topics, in addition to some group projects. All students were required to actively participate in the learning activities done inside classroom. On the other hand, students in the control group were lectured in the topics of the videos by the instructor inside classroom, after that they were required to answer short quizzes in class, and carry out all other activities as homework assignments. At the end of the 10-week treatment, students in both groups were asked to complete a web based survey on engagement, and their course grades were obtained from the course instructor.

\subsection{Instrumentation}

\subsubsection{The Engagement Scale}

To assess the impact of MOOC-based Flipped classroom on students' engagement in learning, the researcher developed Engagement Scale, which consisted of 18 items, distributed on 2 subscales; Cognitive Engagement and Psychological Engagement. The survey is structured around the engagement framework proposed by Fredricks et al. (2004), in which engagement is divided into emotional, cognitive and behavioral components. However, the survey dealt only with the self-reported perceptions on two facets; cognitive and emotional engagement, that's because it is believed that if students are cognitively and motivationally engaged, they are likely to be behaviorally engaged. The survey used five-point Likert scale ranging from 5 (Strongly Agree) to 1 (Strongly Disagree).

\subsubsection{The Engagement Scale Validity}

The validity of the Engagement Scale was assessed in two steps; first, to assess the internal consistency of the scale, Pearson correlation coefficients were calculated between the scores students got on each item and their scores on the sub-scale to which this item belongs. Table (1) shows the correlation coefficients between scores on each item of the scale, and the score on the sub-scale to which this item belongs.

Table 1. Correlation Coefficients between each item, and its Sub-scale

\begin{tabular}{|c|c|c|c|}
\hline $\begin{array}{l}\text { Sub- } \\
\text { Scale }\end{array}$ & Items & $\begin{array}{l}\text { Correlation } \\
\text { Coefficient ( r ) }\end{array}$ & P-value \\
\hline \multirow{9}{*}{ 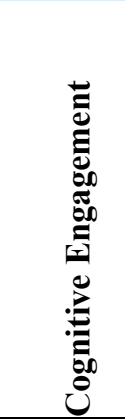 } & 1. I feel immersed in the tasks of this class. & 0.51 & 0.01 \\
\hline & 2. This class keeps me busy and active. & 0.43 & 0.019 \\
\hline & 3. I am encouraged to actively participate in all class activities. & 0.45 & 0.012 \\
\hline & 4. This class gives me the opportunity to learn new things. & 0.75 & 0.01 \\
\hline & 5. I actively seek opportunities to contribute to class. & 0.58 & 0.01 \\
\hline & $\begin{array}{l}\text { 6. I often exert more effort into my study than is required to ensure } \\
\text { success. }\end{array}$ & 0.69 & 0.01 \\
\hline & 7. I often take extra initiative to get things done & 0.84 & 0.01 \\
\hline & 8. Task expectations are clear to me. & 0.42 & 0.02 \\
\hline & 9. I believe that this class increased my knowledge. & 0.75 & 0.01 \\
\hline \multirow{9}{*}{ 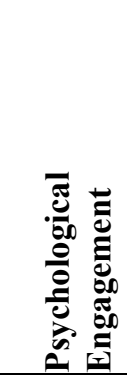 } & 10. I am rewarded and recognized for successful work in this class. & 0.43 & 0.016 \\
\hline & 11. I am enthusiastic about this class. & 0.45 & 0.012 \\
\hline & 12. This class really interests me. & 0.58 & 0.01 \\
\hline & 13. This class is personally fulfilling. & 0.43 & 0.017 \\
\hline & 14. I feel comfortable in this class. & 0.42 & 0.02 \\
\hline & 15. I feel secure and safe in this class. & 0.49 & 0.01 \\
\hline & 16. I am treated fairly in this class. & 0.52 & 0.01 \\
\hline & 17. I am comfortable demonstrating my work to others. & 0.49 & 0.01 \\
\hline & 18. My teacher seems to care about me. & 0.86 & 0.01 \\
\hline
\end{tabular}


As shown in Table (1), all correlation coefficients were between $(0.86-0.42)$, and all significant at the 0.01 level, which indicates that all items are valid.

Second, to assess the internal consistency of the Engagement Scale, Pearson correlations were calculated between the scores students got on each sub-scale and their total scores on the scale. Table (2) shows the correlations between scores on each sub-scale and total score of the Engagement scale.

Table 2. Correlations between scores on each Sub-scale and total score of the Scale

\begin{tabular}{lll}
\hline Sub-scale & Correlation Coefficient ( r ) & P-value \\
\hline Cognitive Engagement & 0.92 & 0.01 \\
\hline Psychological Engagement & 0.91 & 0.01 \\
\hline
\end{tabular}

As shown in Table (2), correlation coefficients were between $(0.0 .92,0.91)$ respectively, and were all significant at the 0.01 , the two subscales have high correlations with the total score of the Engagement Scale, which indicates that they are all valid.

\subsubsection{The Engagement Scale Reliability}

To assess the reliability of the Engagement Scale, alpha Cronbach was calculated for the scale as a whole, and for its two subscales. Table (3) shows Cronbach's Alpha for the Scale as a whole, and its sub-scales.

Table 3. Cronbach's Alpha for the Engagement Scale and its sub scales

\begin{tabular}{lcc}
\hline Scale & Items & Cronbach's Alpha \\
\hline Cognitive Engagement & 9 & 0.78 \\
Psychological Engagement & 9 & 0.76 \\
Engagement in learning & 18 & 0.84 \\
\hline
\end{tabular}

The alpha coefficient of the survey as a whole was 0.84 . The subscale "Cognitive Engagement" had an alpha of 0.78 , and the he subscale "Psychological Engagement" had an alpha of 0.76, which indicates that the survey is reliable.

\section{Results and Discussion}

The overall quantitative data analysis showed that the use of MOOCs in a flipped classroom mode resulted in more engagement in learning and better course grades. Students in the experimental group indicated that they were overall satisfied with the experience, they expressed that it helped them get exposed to high quality materials in the content area they were learning, and engage in more meaningful collaborative tasks, improved their proficiency in English, especially in listening and speaking. In the following sections, results of this study will be presented in the same order of the research questions.

RQ1: Is there a statistically significant difference in engagement in learning between the experimental group (flipped classroom), and control group (traditional classroom)?

Descriptive statistics comparing the scores of the experimental and control group on the engagement scale indicated that the mean score of the experimental group was much higher than that of the control group

Table 4 shows the descriptive statistics of the control and the experimental groups on the engagement in Learning Scale. The mean of the control group on the engagement scale was 31.66 ( $\mathrm{N}=77$ students) with std. deviation of 3.40 , while the mean of the scores on the engagement scale for the experimental group was 62.68 ( $\mathrm{N}=78$ students) with std. deviation of 11.82 .

Table 4. Descriptive Statistics for the control and the experimental groups on Engagement Scale

\begin{tabular}{lllll}
\hline \multirow{2}{*}{ Dimensions } & \multicolumn{2}{c}{ Experimental group $(\mathbf{N}=\mathbf{7 8})$} & \multicolumn{2}{c}{ Control group $(\mathbf{N}=\mathbf{7 7})$} \\
\cline { 2 - 5 } & Mean & SD & Mean & SD \\
\hline Cognitive Engagement & 31.45 & 5.47 & 15.91 & 1.91 \\
Psychological Engagement & 31.23 & 6.89 & 15.75 & 2.38 \\
\hline Engagement in learning & $\mathbf{6 2 . 6 8}$ & $\mathbf{1 1 . 8 2}$ & $\mathbf{3 1 . 6 6}$ & $\mathbf{3 . 4 0}$ \\
\hline
\end{tabular}


Figure 3 shows the mean total scores of the experimental group and control group on the engagement in learning scale.

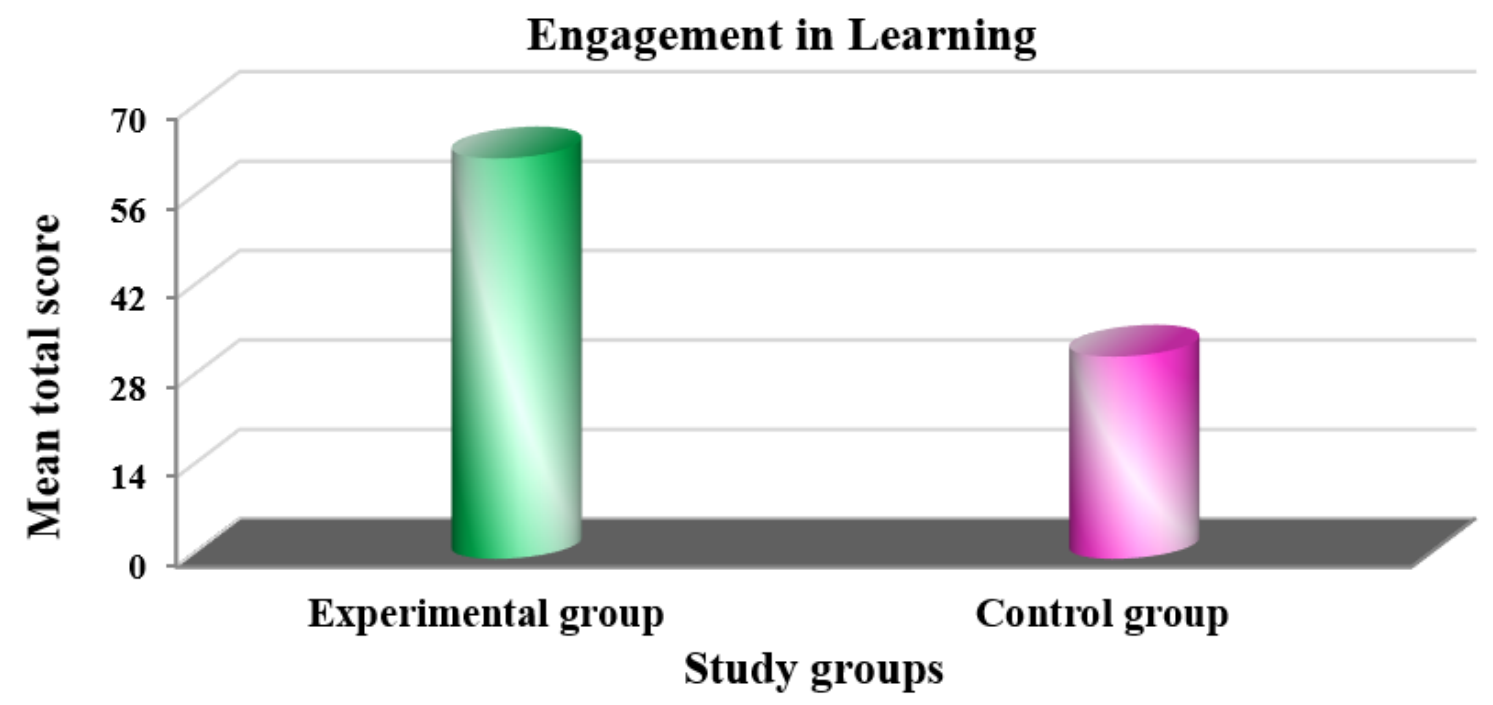

Figure 3. Mean Scores of the Experimental group and Control group on Engagement in Learning Scale

Figure 4. shows the mean scores of the experimental group and control group on Engagement in Learning SubScales, cognitive engagement and psychological engagement.

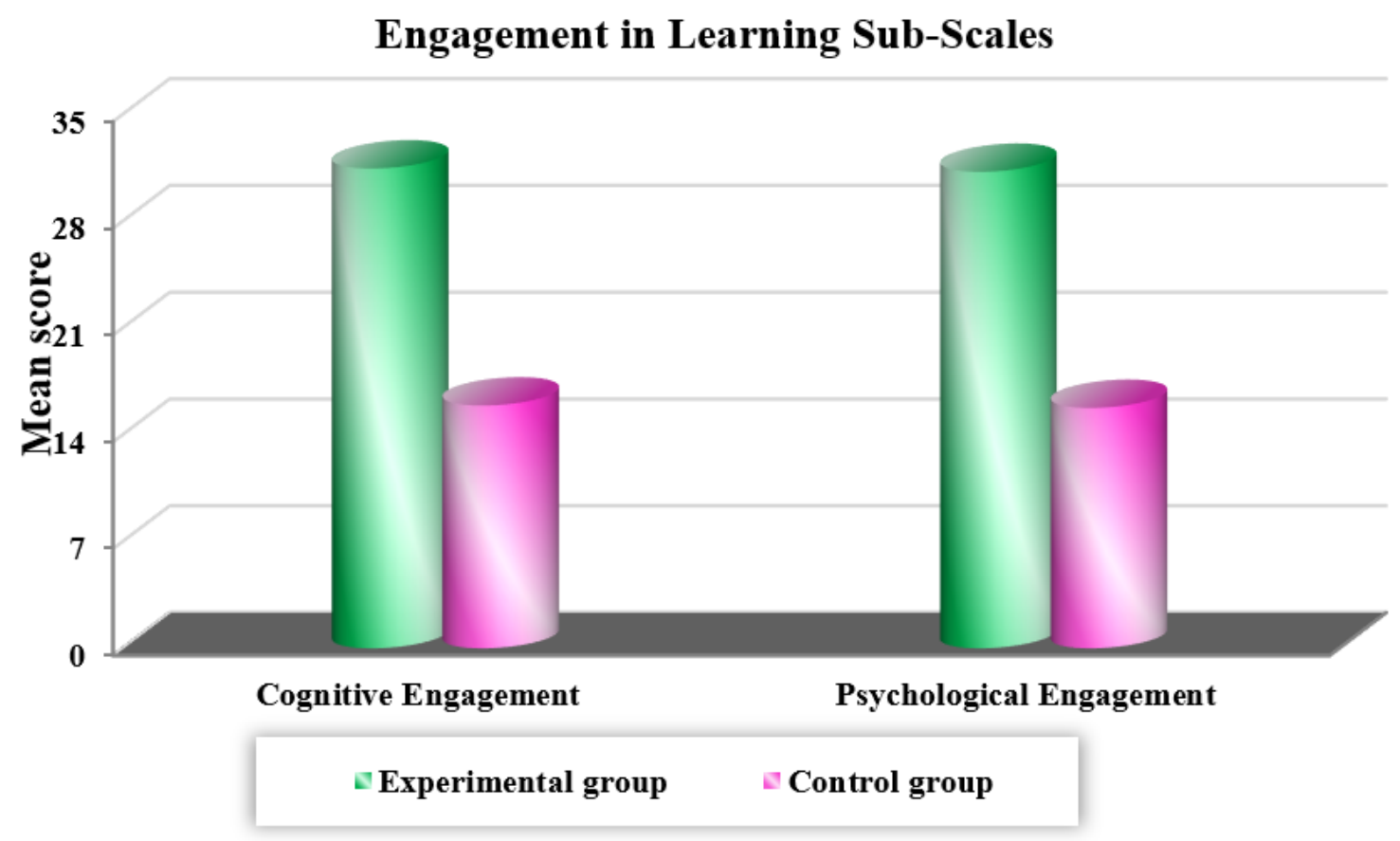

Figure 4. Mean Scores of the Experimental Group and Control Group on Cognitive Engagement and Psychological Engagement Scale

To determine the significance of differences in engagement in learning between the control group and the experimental group, an independent t-test was run. Table 5 shows the results of the Independent samples t-test, and the effect size. 
Table 5. Significance of Differences in Engagement in Learning between the Experimental and Control Group

\begin{tabular}{|c|c|c|c|c|c|c|c|}
\hline \multirow{2}{*}{ Subscale } & \multirow{2}{*}{ Study groups } & \multirow{2}{*}{ Mean } & \multirow{2}{*}{ \pm SD } & \multicolumn{2}{|c|}{ T-test } & \multirow{2}{*}{ Eta square } & \multirow{2}{*}{ Size effec } \\
\hline & & & & $\mathbf{T}$ & DF P-value & & \\
\hline \multirow{2}{*}{ Cognitive Engagement } & Experimental & 31.45 & \pm 5.47 & \multirow{2}{*}{-23.55} & \multirow{2}{*}{0.001} & \multirow{2}{*}{0.78} & \multirow{2}{*}{ Large } \\
\hline & Control & 15.91 & \pm 1.91 & & & & \\
\hline \multirow{2}{*}{ Psychological Engagement } & Experimental & 31.23 & \pm 6.89 & \multirow{2}{*}{-18.64} & \multirow{2}{*}{0.001} & \multirow{2}{*}{0.69} & \multirow{2}{*}{ Large } \\
\hline & Control & 15.75 & \pm 2.38 & & & & \\
\hline Engagement in Learning & $\frac{\text { Experimental }}{\text { Control }}$ & \begin{tabular}{|l|}
62.68 \\
31.66
\end{tabular} & $\begin{array}{l} \pm 11.82 \\
\pm 3.40\end{array}$ & -22.14 & 1530.001 & 0.76 & Large \\
\hline
\end{tabular}

As shown in Table 5, there was a statistically significant difference in favor of the experimental group in cognitive engagement $(t=23.55, p<0.001)$, and in psychological engagement $(t=18.64, p<0.001)$, and in the engagement in learning total score $(\mathrm{t}=22.14, \mathrm{p}<0.001)$. Effect size values for cognitive engagement, psychological engagement, and total engagement were $0.78,0.69$, and 0.76 respectively, which all denote large effect size.

This finding is consistent with literature on flipped classroom which found that flipped classroom enhances student engagement in learning (Baker, 2000; Bergmann \& Sams, 2012; Brown, 2012; Hamdan McKnight, McKnight\& Arfstrom, 2013; Tucker, 2012)._This study revealed that using MOOCs to flip traditional courses improves students' engagement. This can be due to the fact that students were able to use limited class time to engage in higher-level interactive learning activities. There is no fear that technology or video lectures will replace faculty, rather it can make their teaching more effective. Integrating MOOCs and flipped classroom can harness technology to radically redesign teaching and learning experiences.

Integrating MOOCs with flipped classroom into an undergraduate EFLT traditional course over ten weeks resulted in more engagement in learning. Students reported that they had the convenience of watching lecture videos at their own time, at their own pace. They also could pause and repeat watching same videos several times. If they're bored, they can go ahead. When students come to class they felt as if they are reviewing something they have learned before. Pushing lectures out of the classroom is meant to dedicate more and more time for interaction with the instructor and peers, and for discussion and other high quality activities. This is important because it is widely believed that are no substitute for the personal engagement of instructor with students. Students in the flipped classroom also reported that they had the opportunity to interact with high quality course materials, which increased their understanding of the course content. They also expressed their satisfaction with the level of interaction and connectedness they had with the course instructor, which they linked to a better level of learning.

RQ2: Is there a statistically significant difference in course grades between the experimental group (flipped classroom), and control group (traditional classroom)?

This research question examined whether there was a statistically significant difference in course grades between the experimental group who studies using the flipped classroom mode, and the control group who studied in the traditional method. Table 6 shows the descriptive statistics of the control and the experimental groups on Course grades. The mean of the grades for the control group was $51.66(\mathrm{~N}=77$ students) with std. deviation of 10.86, while the mean of the grades for the experimental group was 85.80 ( $\mathrm{N}=78$ students) with std. deviation of 11.82.

Table 6. Descriptive Statistics for the control and the experimental groups on Course Grades

\begin{tabular}{lllll}
\hline & \multicolumn{2}{l}{$\begin{array}{l}\text { Experimental group } \\
(\mathbf{N = 7 8 )}\end{array}$} & \multicolumn{2}{l}{$\begin{array}{l}\text { Control group } \\
(\mathbf{N}=\mathbf{7 7})\end{array}$} \\
\cline { 2 - 5 } & Mean & SD & Mean & SD \\
\hline Course Grades & 85.80 & 11.82 & 51.66 & 10.86 \\
\hline
\end{tabular}

Figure 5 shows the difference in course grades between the experimental and control group. 


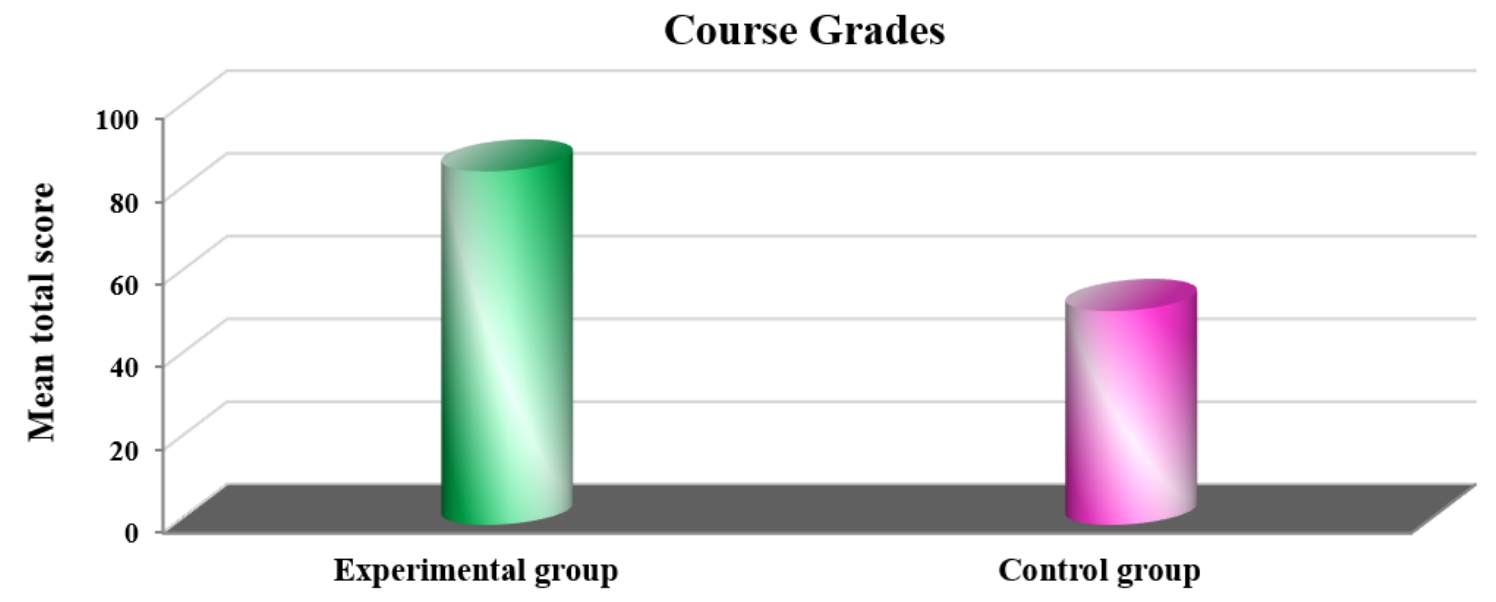

Study Groups

Figure 5. Mean Scores of the Control and Experimental Group on Course Grades

An independent $t$-test was run to determine the significance of differences in course grades between the control group and the experimental group. Table 7 shows the result of t-test and the effect size.

Table 7. Significance of Differences between the Experimental and Control Group on Course Grades.

\begin{tabular}{lllllllll}
\hline & Study groups & Mean & \pm SD & $\frac{T}{\text { T-test }}$ & & & Eta square & $\begin{array}{l}\text { Effect } \\
\text { Size }\end{array}$ \\
\hline Course Grades & Experimental & 85.40 & \pm 10.86 & 25.37 & 153 & 0.001 & 0.81 & Large \\
\cline { 2 - 8 } & Control & 51.30 & \pm 4.63 & & & & &
\end{tabular}

As shown in Table 7, there is a statistically significant difference in course grades in favor of the experimental group ( $\mathrm{t}=25.37, \mathrm{p}<0.001$ ), effect size was 0.81 , which denotes high effect size. This finding echo the findings of previous research that show the positive impact of flipped classroom on learning outcomes (Wen-Chi Vivian Wu, Scott Chen Hsieh \& Jie Chi Yang, 2017; Chen Hsieh, Wu, \& Marek, 2016; Sahin, Cavlazoglu, \&Zeytuncu, 2015; Strayer, 2012; Brunswell and Hrejsi, 2013; Fulton, 2012; Ruddic, 2012; Zappe, Leicht, Mssner, Litzinger, \& Lee, 2009). This finding, on the other hand contradicts the findings of some other research studies that found no significant difference in post-test scores of students who participated in flipped classroom (Johnson \& Renner, 2012).

Though not one of the previously stated research questions, the relationship between engagement in learning and course grades was examined in both flipped classroom setting (experimental group), and traditional classroom setting (control group). To examine the relationship between engagement in learning and course grades, correlation coefficients were calculated, table 8 shows the correlation coefficient between engagement in learning and course grades.

Table 8. Correlation Coefficient between Engagement in Learning and Course Grades

\begin{tabular}{|c|c|c|c|c|c|c|}
\hline Study groups & & Mean & \pm & SD & $\begin{array}{l}\text { Correlation Coefficient } \\
\text { ( r) }\end{array}$ & P-value \\
\hline \multirow{2}{*}{ Experimental } & Engagement & 62.68 & \pm & 11.82 & \multirow{2}{*}{-0.817} & \multirow{2}{*}{0.01} \\
\hline & Course Grades & 85.40 & \pm & 10.86 & & \\
\hline \multirow{2}{*}{ Control } & Engagement & 31.66 & \pm & 3.40 & \multirow{2}{*}{-0.732} & \multirow{2}{*}{0.01} \\
\hline & Course Grades & 51.30 & \pm & 4.63 & & \\
\hline
\end{tabular}

As shown in table $8,(r=0.817,0.732, p<0.01)$ respectively for the experimental and control group, which denote that there is a strong correlation between students' engagement in learning (in both experimental and control group) and their course grades. The more students are engaged in learning, the more their grades are, Figure 6 and 7 show 
this relationship between engagement in learning and course grades for the experimental and control group respectively.

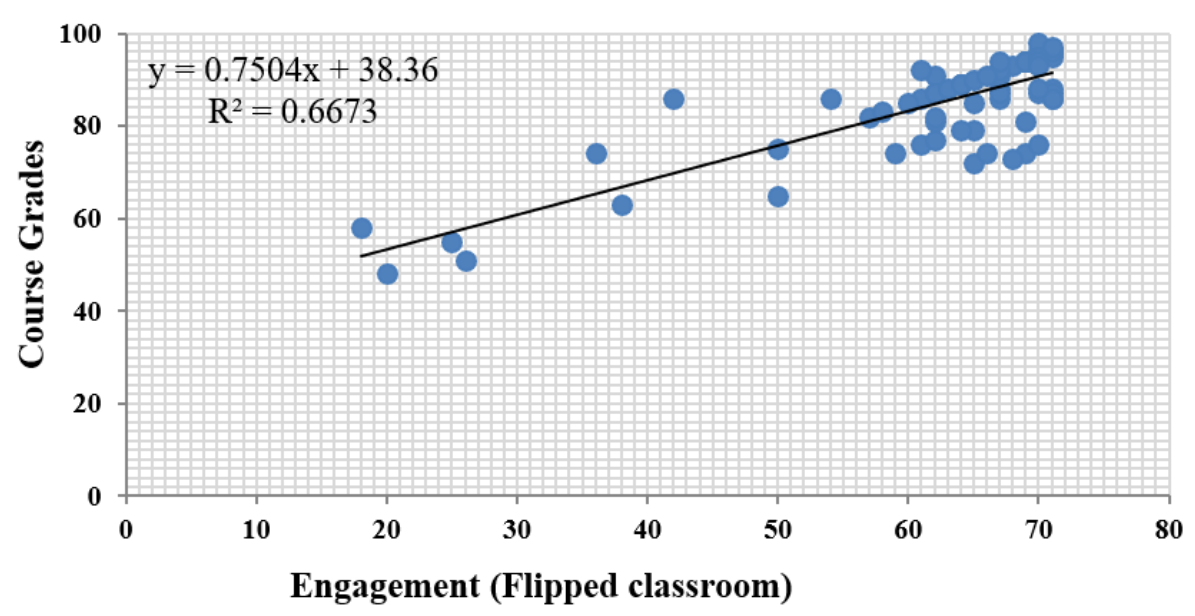

Figure 6. The Correlation between Engagement in Learning and Course Grades for the Experimental Group

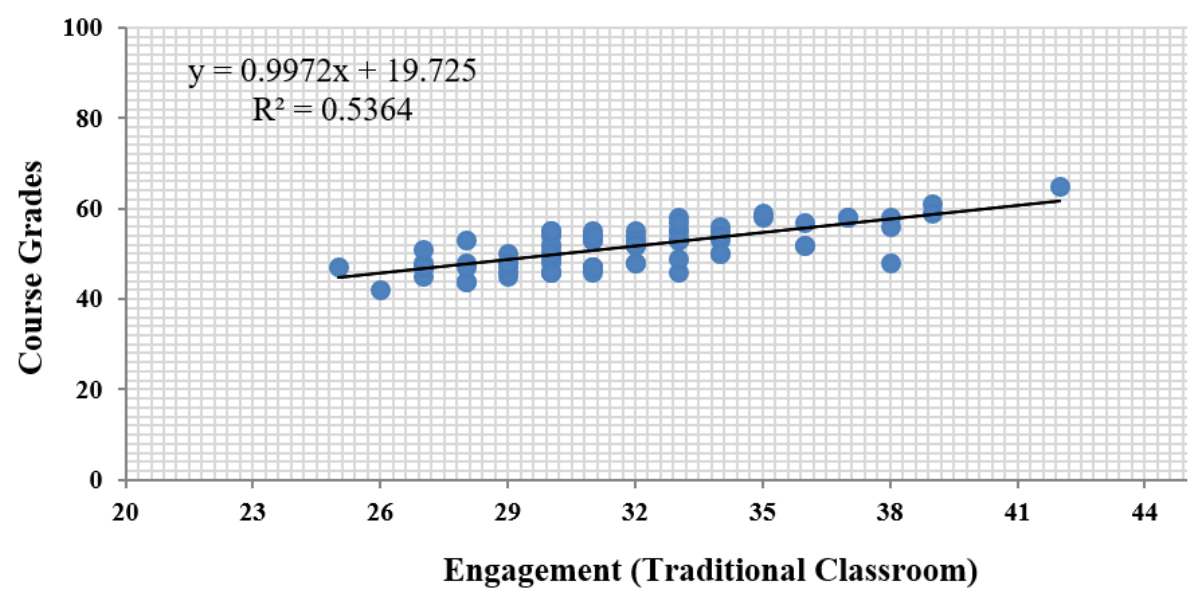

Figure 7. The Correlation between Engagement in Learning and Course Grades for the Control Group

As shown in Table 8, there is a strong correlation between engagement in learning and course grades for both flipped classroom $(r=0.817, p<0.01)$ and traditional classroom group $(r=0.732 p<0.01)$. This finding substantiate the findings of prior research which established that students' engagement in learning is linked to better learning outcomes (Abdel-Maksoud, 2007; Kuh, 2003; Fredricks et al., 2004; Pascarella \& Terenzini, 2005). Engagement in learning was linked to students' satisfaction with the course and students grades. Students who reported higher degrees of engagement in learning were more satisfied with the course and achieved better than their classmates. Interaction was correlated with students' engagement in learning. Students who perceived interaction to be high were more engaged with learning than the others.

The findings of this study can be explained in the light of the Constructivist theory (Bruner, 1966), because the flipped classroom does allow students to construct their thoughts and concepts prior to class from the videos they watch. Learners then come to class to complete the assignments or projects through engaging in discussions and meaningful activities, and interacting with the instructor and their peers. This allows learners to understand and apply their learning in the higher learning taxonomies. Flipped classroom effectively makes students more independent active learners in which they construct new ideas and concepts prior to class.

Research findings are also supported by the Social Learning theory. Bandura's (1977) Social Learning theory explains that human behavior is a continuous reciprocal interaction between cognitive, behavioral, and environmental influences. The theory suggests that a continuous interaction in the classroom between instructor and learners and students and peers support learning. According to Bandura (1977), human behavior is learned 
observationally through modeling. Flipped classroom allows students to observe and socially interact with their peers and teachers while completing assignments and projects in class. Students have their peers and their teacher readily available for guidance and modeling if additional support is needed.

\section{Conclusion}

During the last two years, MOOCs are proving to be extremely popular. Though there are many problems associated with MOOCs as stand-alone online courses, they can be effectively integrated with flipped classroom mode. MOOCs can greatly accelerate the introduction of flip teaching in higher education. MOOCs can be seen as a supplement to traditional courses, rather a replacement for them. Actually, flipping the classroom is one of the typical uses of MOOCs (Kay, Reimann, Diebold \& Kummerfeld, 2013; Martin, 2012). Daphne Koller, one of Coursera founders, was an early Stanford promoter of Flipped classroom paradigm that mixes video-based instruction, and automated assessment, accessed in a MOOC with interactive face to face classes.

The findings of this study show that the flipped classroom intervention significantly impacted students' cognitive and psychological engagement in learning, and their course grades. In the 10-week intervention, experimental group students had to enroll in two MOOCs dealing with the same topics of the course, access the materials and watch videos posted to MOOCs before they come to class. Class time was devoted to work in small teams, engage in classroom activities, ask and answer questions, and get immediate feedback from the course instructor. All this proved to be effective in enhancing engagement and learning.

Flipping courses with high quality MOOCs materials allowed for more engagement in learning and more course grades. Students also indicted that they had improved experience, immediate feedback, were overall positive, the only objection was that the time allocated for watching online videos, and taking notes, consumed more time than expected. Applying a MOOC in an EFLT flipped classroom proved helpful to enhance students' learning outcomes, and develop students' ability to self-learning and interpersonal interaction. This teaching strategy can be extended and applied to other topics more opportunity to interact with course instructor, and with one another.

Students also expressed their satisfaction of the materials and videos posted to the two MOOCs they enrolled in, and reported that this increased not only their learning of the content area, but also improved their English listening and speaking skills. This exciting finding might encourage researchers to examine the impact of English MOOCs on English language proficiency. The positive findings of the current study are consistent with other research findings that reported positive effects of flipped classroom (i.e., Freeman et al., 2014; Bergmann \& Sams, 2012; Finkel, 2012). The findings of this study can also add further weight to an emerging consensus that MOOCs can be integrated with traditional better engagement and learning outcomes. Contrary to Other studies that reported null effect of flipped classroom on achievement and course grades (i.e. Overmyer, 2014; Willis, 2014), this study found positive effect on course grades. By integrating MOOCs and flipped classroom mode into traditional courses, we can achieve better learning outcomes and experiences. Integrating MOOCs with flipped classroom strategy can bring the best of both worlds.

\section{Limitations}

This study dealt only with one group of undergraduate students at one educational institution, so findings from this one class may not necessarily be generalizable to other settings. Studying larger populations from different disciplines need to be conducted. This study is understandably limited in scope, but does provide important ground work for future investigations.

\section{References}

Abdel-Maksoud, N. F. (2007). Interaction as a predictor of students' satisfaction and students' grades in distance education. Dissertation Abstracts International, 68(5). (UMI No. 3269240)

Adamopoulos, P. (2013). What makes a great MOOC? An interdisciplinary analysis of student retention in online courses, in Proceedings of Thirty Fourth International Conference on Information Systems, Milan 2013.

Alraimi, K. M., Zo, H., \& Ciganek, A. P. (2015). Understanding the MOOCs continuance: The role of openness and reputation. Computers \& Education, 80, 28-38. https://doi.org/10.1016/j.compedu.2014.08.006

Armellini, A., \& Padilla Rodriguez, B. C. (2016). Are massive open online courses (MOOCs) pedagogically innovative? Journal of Interactive Online Learning, 14(1), 17-28.

Baker, J. W. (2000). The "Classroom Flip": Using web course management tools to become the guide by the side. In J. A. Chambers (Eds.) Selected papers from the 11th International Conference on College Teaching and Learning (pp. 9-17). Retrieved from ERIC database. (ED440975).

Bandura, A. (1977). Social learning theory. New York: General Learning Press. 
Basal, A. (2015). The implementation of a flipped classroom in foreign language teaching. Turkish Online Journal of Distance Education, 16(4), 28-37. https://doi.org/10.17718/tojde.72185

Bergmann, J., \& Sams, A. (2012). Flip your classroom: Reach every student in every class every day. International society for technology in education. Retrieved February 9, 2018 from https://s3.amazonaws.com/academia.edu.documents/40900327/Flip_Your_Classroom-

Reach_Every_Student_in_Every_Class_Every_Day.pdf?AWSAccessKeyId=AKIAIWOWYYGZ2Y53UL3 A\&Expires $=1556970119 \&$ Signature $=0$ RsFqUBOT1XHB76lwbsc3W\%2BCDbk\%3D\&response-contentdisposition $=$ inline $\% 3 \mathrm{~B} \%$ 20filename\%3D40900327.pdf

Breslow, L. B., Pritchard, D. E., DeBoer, J., Stump, G. S. , Ho, A. D., \& Seaton, D. T. (2013). "Studying Learning in the Worldwide Classroom: Research into edX's first MOOC." Research \& Practice in Assessment, 8, 1325.

Brown, A. (2012). A Phenomenological Study of Undergraduate Instructors using the Inverted or Flipped Classroom Model. (Doctoral dissertation). Retrieved from ProQuest UMI. (3545198).

Bruff, D. O., Fisher, D. H., McEwen, K. E., \& Smith, B. E. (2013). Wrapping a MOOC: Student perceptions of an experiment in blended learning. Journal of Online Learning and Teaching, 9(2), 187.

Bruner, J. S. (1966). Toward a theory of instruction. W. W. Norton and Company, Inc. New York.

Brunsell, E., \& Horejsi, M. (2013). Flipping your classroom in one "take". The Science Teacher, 80(3), 8. Retrieved from http://go.galegroup.com

Bryson, C., \& Hand, L. (2007). The role of engagement in inspiring teaching and learning. Innovations in Education and Teaching International, 44(4), 349-362. https://doi.org/10.1080/14703290701602748

Caulfield, M., Collier, A., \& Halawa, S. (2013, October 7). Rethinking online community in MOOCs used for blended learning [Web log post]. Retrieved February 2019 from http://www.educause.edu/ero/article/rethinking-online-community-moocs-used-blended-learning

Chen Hsieh, J. S., Wu, W. C. V., \& Marek, M. W. (2016). Using the flipped classroom to enhance EFL learning. Computer Assisted Language Learning, 1-25. https://doi.org/10.1080/09588221.2015.1111910

Clow, D. (2013). Moocs and the Funnel of Participation, in Proceedings of the Third International Conference on Learning Analytics and Knowledge (pp. 185-189). Leuven, Belgium: ACM. https://doi.org/10.1145/2460296.2460332

Crosslin, M., Dellinger, J. T., Joksimovic, S., Kovanovic, V., \& Gaševic, D. (2018). Customizable Modalities for Individualized Learning: Examining Patterns of Engagement in Dual-Layer MOOCs. Online Learning, 22(1), 19-38. https://doi.org/10.24059/olj.v22i1.1080

Dabbagh, N., Benson, A. D., Denham, A., Joseph, R., Al-Freih, M., Zgheib, G., ... \& Guo, Z. (2016). Massive open online courses. In Learning technologies and globalization (pp. 9-13). Springer, Cham. https://doi.org/10.1007/978-3-319-22963-8

de Barba, P. G., Kennedy, G. E., \& Ainley, M. D. (2016). The role of students' motivation and participation in predicting performance in a MOOC. Journal of Computer Assisted Learning, 32(3), 218-231. https://doi.org/10.1111/jcal.12130

Delialioglu, Ö. (2012). Student engagement in blended learning environments with lecture-based and problembased instructional approaches. Journal of Educational Technology \& Society, 15(3), 310-322.

Doyle, T. (2008). Helping students learn in a learner-centered environment: A guide to facilitating learning in higher education. Sterling, VA: Stylus Publishing.

Fidalgo-Blanco, Á., Sein-Echaluce, M. L., \& García-Peñalvo, F. J. (2016). From massive access to cooperation: lessons learned and proven results of a hybrid $\mathrm{xMOOC/cMOOC}$ pedagogical approach to MOOCs. International Journal of Educational Technology in Higher Education, 13(1), 24. https://doi.org/10.1186/s41239-016-0024-z

Finkel, E. (2012). Flipping the Script in K-12. District Administration, 48(10), 28. Retrieved March 4 from http://goo.gl/bU6sOq

Firmin, R., Schiorring, E., Whitmer, J., Willett, T., Collins, E. D., \& Sujitparapitaya, S. (2014). Case study: Using MOOCs for conventional college coursework. Distance Education, 35(2), 178-201. https://doi.org/10.1080/01587919.2014.917707 
Fondo, M., \& Konstantinidis, A. (2018). Design of a MOOC on personal language learning environments for digital language skills development. In P. Taalas, J. Jalkanen, L. Bradley \& S. Thouësny (Eds), Futureproof CALL: language learning as exploration and encounters - short papers from EUROCALL 2018 (pp. 64-69). Researchpublishing.net. https://doi.org/10.14705/rpnet.2018.26.814

Franzon, P. D. (2013, June). MOOCs, OOCs, flips and hybrids: The new world of higher education. In 2013 IEEE International Conference on Microelectronic Systems Education (MSE) (pp. 13-13). IEEE. https://doi.org/10.1109/MSE.2013.6566692

Fredricks, J. A., Blumenfeld, P. C., \& Paris, A. H. (2004). School Engagement: Potential of the concept, state of the evidence. Review of Educational Research, 74(1), 59-109. https://doi.org/10.3102/00346543074001059

Fredricks, J. A., Filsecker, M., \& Lawson, M. A. (2016). Student engagement, context, and adjustment: Addressing definitional, measurement, and methodological issues. Learning and Instruction, 43, 1-4. https://doi.org/10.1016/j.learninstruc.2016.02.002

Freitas, S. I., Morgan, J., \& Gibson, D. (2015). Will MOOCs transform learning and teaching in higher education? Engagement and course retention in online learning provision. British Journal of EducationalTechnology, 46(3), 455-471. https://doi.org/10.1111/bjet.12268

Fulton, K. (2012). Upside down and inside out: Flip your classroom to improve student learning. Learning \& Leading with Technology, 39(8), 12-17.

Graziano, K. J. (2017). Peer teaching in a flipped teacher education classroom. TechTrends, 61(2), 121-129. https://doi.org/10.1007/s11528-016-0077-9

Griffiths, R., Chingos, M., Mulhern, C., \& Spies, R. (2014). Interactive online learning on campus: Testing MOOCs and other platforms in hybrid formats in the University System of Maryland (ITHAKA S+R Report). https://doi.org/10.18665/sr.22522

Hamdan, N., McKnight, P., McKnight, K., \& Arfstrom, K. M. (2013). The flipped learning model: A white paper based on the literature review titled "A review of flipped learning." Arlington, VA: Flipped Learning Network.

Hawks, S. J. (2014). The flipped classroom: now or never? AANA journal, 82(4), 264-296.

Hew, K. F., \& Cheung, W. S. (2014). Students' and instructors' use of massive open online courses (MOOCs): Motivations and challenges. Educational Research Review, 12, 45-58. https://doi.org/10.1016/j.edurev.2014.05.001

Hollands, F. M., \& Tirthali, D. (2014). MOOCs: expectations and reality. Full report. Retrieved from http://cbcse.org/wordpress/wp-content/uploads/2014/05/MOOCs_Expectations_and_Reality.pdf

Holotescu, C., Grosseck, G., Cretu, V., \& Naaji, A. (2014). Integrating MOOCs in blended courses. Proceedings of the International Scientific Conference of eLearning and Software for Education, Bucharest, 243-250. https://doi.org/10.12753/2066-026X-14-034

Hsu, T. C. (2017). Behavioural sequential analysis of using an instant response application to enhance peer interactions in a flipped classroom. Interactive Learning Environments, 1-15. https://doi.org/10.1080/10494820.2017.1283332

Jaffer, T., Govender, S., \& Brown, C. (2017). “The best part was the contact!” Understanding Postgraduate students' experiences of wrapped MOOCs', Open Praxis, 9(2), 207-221. https://doi.org/10.5944/openpraxis.9.2.565.

Jang, H. (2008). Supporting students' motivation, engagement, and learning during an uninteresting activity. Journal of Educational Psychology, 100(4), 798-811. https://doi.org/10.1037/a0012841

Jinlei, Z., Ying, W., \& Baohui, Z. (2012). Introducing a New Teaching Model: Flipped Classroom [J]. Journal of Distance Education, 4(8), 46-51.

Johnson, L., \& Renner, J. (2012). Effect of the flipped classroom model on secondary computer applications course: Student and teacher perceptions, questions and student achievement (Doctoral dissertation, University of Louisville). Retrieved from https://theflippedclassroom.files.wordpress.com/2012/04/johnson-renner2012.pdf

Johnson-Farmer, B., \& Frenn, M. (2009). Teaching excellence: What great teachers teach us. Journal of Professional Nursing, 25(5), 267-272. https://doi.org/10.1016/j.profnurs.2009.01.020

Johnston, B. M. (2017). Implementing a flipped classroom approach in a university numerical methods mathematics course. International Journal of Mathematical Education in Science and Technology, 48(4), 
485-498. https://doi.org/10.1080/0020739X.2016.1259516

Jordan, K. (2014). Initial trends in enrolment and completion of massive open online courses. The International Review of Research in Open and Distributed Learning, 15(1), 133-160. https://doi.org/10.19173/irrodl.v15i1.1651

Kay, J, Reimann, P., Diebold, E., \& Kummerfeld, B. (2013). "MOOCs: so many learners, so much potential," IEEE Intelligent Systems, 28(3), 70-77. https://doi.org/10.1109/MIS.2013.66

Kember, D. (2009). Promoting student-centred forms of learning across an entire university. Higher education, 58(1), 1-13. https://doi.org/10.1007/s10734-008-9177-6

Klem, A. M., \& Connell, J. P. (2004). Relationships matter: Linking teacher support to student engagement and achievement. Journal of School Health, 74(7), 262-273. https://doi.org/10.1111/j.1746-1561.2004.tb08283.x

Kovanović, V., Joksimović, S., Gašević, D., Siemens, G., \& Hatala, M. (2015). What public media reveals about MOOCs: A systematic analysis of news reports. British Journal of Educational Technology, 46(3), 510-527. https://doi.org/10.1111/bjet.12277

Kuh, G. D. (2003). What we're learning about student engagement from NSSE, Change, 35(2), 24-32. https://doi.org/10.1080/00091380309604090

Lewin, T. (2013, February 20). Universities Abroad Join Partnerships on the Web. The New York Times. Retrieved February 2019 from http://www.nytimes.com/2013/02/21/education/universities-abroad-joinmooc-courseprojects.html?_r=0

Linnenbrink, E. A., \& Pintrich, P. R. (2003). The role of self-efficacy beliefs in student engagement and learning in the classroom. Reading \&Writing Quarterly, 19(2), 119-137. https://doi.org/10.1080/10573560308223

Luján-Mora, S., Saquete, E. (2013). Mixing a MOOC with flip teaching in a traditional classroom Proceedings of the 5th International Conference on Education and New Learning Technologies (Edulearn 2013), p. 64806487, Barcelona (Spain), July 1-3 2013. ISBN: 978-84-616-3822-2.

Lumpkin, A., Achen, R. M., \& Dodd, R. K. (2015). Student perceptions of active learning. College Student Journal, 49(1), 121-133.

Mackness, J., Mak, S., \& Williams, R. (2010). The ideals and reality of participating in a MOOC. In Proceedings of the 7th International Conference on Networked Learning, May 3-4, pp. 266-274.

Martin, F. G. (2012). "Will massive open online courses change how we teach? Sharing recent experiences with an online course," Communications of the ACM, 55(8), 26-28. https://doi.org/10.1145/2240236.2240246

Massachusetts Institute of Technology (2012). MIT and Harvard announce edX. MITnews Retrieved February 2019 from http://web.mit.edu/newsoffice/2012/mit-harvard-edx-announcement-050212.html

Massachusetts Institute of Technology. (2011). MIT launches online learning initiative. MITnews, Retrieved February 2019 from http://web.mit.edu/newsoffice/2011/mitx-education-initiative-1219.html

McAuley, A., Stewart, B., Siemens, G., Dave Cormier, D. (2010). Massive Open Online Courses Digital ways of knowing and learning, The MOOC model For Digital Practice, Retrieved February 2019 from https://oerknowledgecloud.org/sites/oerknowledgecloud.org/files/MOOC_Final.pdf

Miller, R. B., \& Brickman, S. J. (2004). A model of future-oriented motivation and self-regulation. Educational Psychology Review, 16, 9-33. https://doi.org/10.1023/B:EDPR.0000012343.96370.39

Molnar, K. K. (2017). What effect does flipping the classroom have on undergraduate student perceptions and grades? Education and Information Technologies, 22(6), 2741-2765. https://doi.org/10.1007/s10639-0169568-8

Newmann, F., Wehlage , G., \& Lamborn, S. (1992). The significance and sources of student engagement. In F. Newmann (Ed.), Student engagement and achievement in American secondary schools (pp. 11-39). New York, NY: Teachers College, Columbia University. https://doi.org/10.4236/ojapps.2014.45022

Ng, A., \& Widom, J. (2014). Origins of the modern MOOC (xMOOC). In F. M. Hollands, \& D. Tirthali (Eds.), MOOCs: Expectations and reality. Full report (pp. 34e41). New York, USA: Center for Benefit-Cost Studies of Education. Teachers College. Columbia University. Retrieved from http://cbcse.org/wordpress/wp-content/ uploads/2014/05/MOOCs_Expectations_and_Reality.pdf

O'Flaherty, J., \& Phillips, C. (2015). The use of flipped classrooms in higher education: a scoping review. The Internet and Higher Education, 2585-2595. https://doi.org/10.1016/j.iheduc.2015.02.002 
Onah, D. F., Sinclair, J., Boyatt, R., \& Foss, J. (2014). Massive open online courses:Learner participation. Paper presented at the Proceeding of the 7th International Conference of Education, Research and Innovation, Seville, Spain.

Overmyer, G. R. (2014). The flipped classroom model for college algebra: Effects on student achievement (Doctoral dissertation, Colorado State University).

Pascarella, E. T., \& Terenzini, P. T. (2005). How college affects students: A third decade of research (2nd ed.). San Francisco: Jossey-Bass Publishers.

Pilotti, M., Anderson, S., Hardy, P., Murphy, P., \& Vincent, P. (2017). Factors Related to Cognitive, Emotional, and Behavioral Engagement in the Online Asynchronous Classroom. International Journal of Teaching and Learning in Higher Education, 29(1), 145-153.

Pintrich, P. R., \& Schunk, D. H. (1996). Motivation in education: Theory, research and applications. Englewood Cliffs, NJ: Prentice Hall Merrill.

Reeve, J., Jang, H., Carrell, D., Jeon, S., \& Barch, J. (2004). Enhancing students' engagement by increasing teachers' autonomy support. Motivation and Emotion, 28(2), 147-169. https://doi.org/10.1023/B:MOEM.0000032312.95499.6f

Roehling, P. V., Root Luna, L. M., Richie, F. J., \& Shaughnessy, J. J. (2017). The benefits, drawbacks, and challenges of using the flipped classroom in an introduction to psychology course. Teaching of Psychology, 44(3), 183-192. https://doi.org/10.1177/0098628317711282

Ruddick, K. W. (2012). Improving chemical education from high school to college using a more hands-on approach. (Doctoral dissertation). Retrieved from ProQuest. (1082023572)

Sahin A., Cavlazoglu, B., \& Zeytuncu, Y. E. (2015). Flipping a college calculus course: A Case study. Educational Technology \& Society, 18(3), 142-152.

Sandeen, C. (2013). Integrating MOOCS into Traditional Higher Education: The Emerging "MOOC 3.0" Era. Change: The Magazine of Higher Learning, 45(6), 34-39. https://doi.org/10.1080/00091383.2013.842103

Schlenker, B. R., Schlenker, P. A., \& Schlenker, K. A. (2013). Antecedents of academic engagement and the implications for college grades. Learning and Individual Differences, $27,75-81$. https://doi.org/10.1016/j.lindif.2013.06.014

Shah, D. (2018). Year of MOOC-based Degrees: A Review of MOOC Stats and Trends in 2018, ClassCentral MOOCREPORT. https:/www.class-central.com/report/moocs-stats-and-trends-2018/

Shell, D. F., \& Husman, J. (2001). The multivariate dimensionality of personal control and future time perspective in achievement and studying. Contemporary Educational Psychology, 26, 481-506. https://doi.org/10.1006/ceps.2000.1073

Siemens, G. (2013). Massive Open Online Courses: Innovation in education? In R. McGreal, W. Kinuthia \& S. Marshall (Eds.), Open Educational Resources: Innovation, Research and Practice (pp. 5-15). Vancouver: Commonwealth of Learning and Athabasca University.

Siemens, G. (July 25, 2012). MOOCs are really a platform. [Blog post]. Elearnspace. Retrieved February 2019 from http://www.elearnspace.org/blog/2012/07/25/moocs-arereally-a-platform/

Song, Y., \& Kapur, M. (2017). How to flip the classroom- "Productive failure or traditional flipped classroom" pedagogical design? Journal of Educational Technology \& Society, 20(1), 292. Retrieved March 2019 from https://www.jstor.org/stable/pdf/jeductechsoci.20.1.292.pdf

Stone, B. B. (2012). Flip your classroom to increase active learning and student engagement. Paper presented at the 28th Annual Conference on Distance Teaching and Learning, Madison, WI. http://www.uwex.edu/disted/conference/Resource_library/proceedings/56511_2012.pdf

Strayer, J. F. (2012). How learning in an inverted classroom influences cooperation, innovation and task orientation. Learning Environments Research, 15, 171-193. https://doi.org/10.1007/s10984-012-9108-4

Thompson, C. (2011), How Khan Academy is changing the rules of education. Wired Magazine, 126, 1-5.

Troisi, J. D. (2014). Making the grade and staying engaged: The influence of student management teams on student classroom outcomes. Teaching of Psychology, 41(2), 99-103. https://doi.org/10.1177/0098628314530337

Tucker, B. (2012). The flipped classroom. Education next, 12(1), 82-83. 
Uvalić-Trumbić, S., \& Daniel, J. (2013, September). Making sense of MOOCs: The evolution of online learning in higher education. In European Conference on Technology Enhanced Learning (pp. 1-4). Springer, Berlin, Heidelberg. https://doi.org/10.1007/978-3-642-40814-4_1

Valdivia, J. A., Ramírez -Montoya, M. S., \& Valenzuela, J. R. (2018). Motivation and knowledge: Pre-assessment and post -assessment of MOOC participants from an energy and sustainability project. International Review of Research in Open and Distributed Learning, 19(4). https://doi.org/10.19173/irrodl.v19i4.3489

Watson, S. L., Watson, W. R., Yu, J. H., Alamri, H., \& Mueller, C. (2017). Learner profiles of attitudinal learning in a MOOC: An explanatory sequential mixed methods study. Computers \& Education, 114, 274-285. https://doi.org/10.1016/j.compedu.2017.07.005

Webber, K. L., Krylow, R. B., \& Zhang, Q. (2013). Does involvement really matter? Indicators of college student success and satisfaction. Journal of College Student Development, 54(6), 591-611. https://doi.org/10.1353/csd.2013.0090

Wiginton, B. L. (2013). Flipped instruction: An investigation into the effect of learning environment on student self-efficacy, learning style, and academic achievement in an algebra I classroom. (Doctoral dissertation). The University of Alabama. Retrieved from https://search.proquest.com/docview/1505373684?pqorigsite $=$ gscholar

Willis, J. A. (2014). The effects of flipping an undergraduate precalculus class (Doctoral dissertation, Appalachian State University).

Wu, W. C. V., Chen, S. H. J., \& Yang, J. C. (2017). Creating an Online Learning Community in a Flipped Classroom to Enhance EFL Learners' Oral Proficiency. Journal of Educational Technology \& Society, 20(2), 142-157. Retrieved from http://search.ebscohost.com.sdl.idm.oclc.org/login.aspx?direct=true \&db=ehh\&AN=122353866\&site=edslive

York, T. T., Gibson, C., \& Rankin, S. (2015). Defining and measuring academic success. Practical Assessment. Research \& Evaluation, 20(5), 1-20. Retrieved from $\mathrm{http}: / /$ pareonline.net/getvn.asp?v=20\&n=5

Yousef, A. M. F., Chatti, M. A., Schroeder, U., \& Wosnitza, M. (2015). A usability evaluation of a blended MOOC environment: An experimental case study. The International Review of Research in Open and Distributed Learning, 16(2), 69-93. https://doi.org/10.19173/irrodl.v16i2.2032

Zappe, S., Leicht, R., Messner, J., Litzinger, T., \& Lee, H. W. (2009, June). "Flipping” the classroom to explore active learning in a large undergraduate course. Paper presented at 2009 Annual Conference \& Exposition, Austin, TX.

Zeeman, E., \& Lotriet, M. (2013). Beyond the expected: an enriched learning experience through learner engagement and participation. Teaching in Higher Education, 18(2), 179-191. https://doi.org/10.1080/13562517.2012.696540

Zengin, Y. (2017). Investigating the use of the Khan Academy and mathematics software with a flipped classroom approach in mathematics teaching. Journal of Educational Technology \& Society, 20(2), 89-100. Retrieved from http://www.jstor.org/stable/90002166

\section{Copyrights}

Copyright for this article is retained by the author(s), with first publication rights granted to the journal.

This is an open-access article distributed under the terms and conditions of the Creative Commons Attribution license (http://creativecommons.org/licenses/by/4.0/). 